Volume 3 No. 1 Maret 2019

P-ISSN 2550-0805 E-ISSN 2550-0791

http://ejournal.bsi.ac.id/ejurnal/index.php/widyacipta

\title{
Pengaruh Komitmen Organisasi dan Iklim Organisasi Terhadap Tindakan WhistleBlowing
}

\author{
Devy Sofyanty \\ Program Studi Komputer Akuntasi \\ Universitas Bina Sarana Informatika \\ Email: devy.dyy@bsi.ac.id
} Cara Sitasi: Sofyanty, D. (2019). Pengaruh Komitmen Organisasi dan Iklim Organisasi Terhadap Tindakan
WhistleBlowing. Widya Cipta, 3(1), 43-50.

\begin{abstract}
Cheating like corruption and various financial scandals happened lately, whistleblowing deemed necessary to minimize those frauds. Research is aimed to analyze the influence of organizational commitment and organizational climate toward whistleblowing action. This type of research is the study of causality, methods using purposive sampling techniques. The data used in the research is the primary data collected through a questionnaire survey in government auditors (internal auditors) who work at Badan Pengawasan Keuangan dan Pembangunan (BPKP) Jakarta Province Representation. A total respondents used in this research is 200 respondents. Based on the results of the research, then obtained the following findings: (1) simultaneous organizational commitment and organizational climate positive and significant impact on whistleblowing action, (2) partially organizational commitment positive and significant impact on whistleblowing action, (3) partially organizational climate positive and significant effect on whistleblowing action. It shows that the better organizational commitment and organizational climate, the higher of whistleblowing action.
\end{abstract}

Keywords: Organizational Commitment, Organizational Climate, Whistleblowing Action

\section{PENDAHULUAN}

Maraknya tindak kecurangan dalam bentuk pemalsuan, mark up dalam laporan keuangan, penyalahgunaan asset perusahaan, sampai kasus korupsi yang terjadi pada sektor pemerintahan mendapat perhatian serius dari publik. Kecurangan atau fraud merupakan tindakan yang dilakukan karena ada kesempatan, tekanan, konformitas bahkan pembenaran atas penguatan atas apa yang dilakukan oleh seseorang, rekan kerja bahkan atasan. Fraud tentu saja harus ditindaklanjuti dan menjadi tanggung jawab semua pihak yang terlibat dalam organisasi tersebut, salah satu tindakan preventif bahkan solusi yang dilakukan adalah dengan melaporkan tindakan kecurangan, tindakan ini disebut dengan istilah whistleblowing. Whistleblowing adalah pelaporan yang dilakukan oleh anggota organisasi (aktif maupun nonaktif) mengenai pelanggaran, tindakan ilegal atau tidak bermoral kepada pihak di dalam maupun di luar organisasi. Menjadi whistleblower merupakan tindakan yang berisiko karena terdapat ancaman fisik dan psikis baik secara langsung maupun tidak langsung dari pihak tertentu yang mengakibatkan whistleblower merasa takut dan dipaksa untuk melakukan atau tidak melakukan sesuatu yang berkenaan dengan kesaksiannya dalam suatu kasus. (Tuanakotta, 2010).

Menurut Keraf dalam (Arsana, 2018) ada dua macam whistleblowing yaitu whistle blowing internal dan eksternal. Whistleblowing internal terjadi ketika seseorang atau beberapa orang karyawan tahu mengenai kecurangan yang dilakukan karyawan lain atau kepala bagiannya kemudian melaporkan kecurangan itu kepada pimpinan perusahaan yang lebih tinggi. Motivasi utama dari whistleblowing adalah motivasi moral demi mencegah kerugian bagi perusahaan tersebut. Karena itu, pimpinan yang diberi tahu harus bersikap hati-hati dan netral dalam menanggapi laporan itu. Netral bukan dalam pengertian tidak peduli (indifferent), melainkan serius menanggapinya tetapi dengan tetap memegang prinsip praduga tak bersalah. Artinya, disatu pihak laporan itu bisa benar dan di pihak lain motivasi pelapor bisa saja memang baik tapi bisa juga tidak baik. Sedangkan Whistleblowing ekternal menyangkut kasus dimana seorang pekerja mengetahui kecurangan yang dilakukan perusahaannya lalu membocorkannya kepada masyarakat karena dia tahu bahwa kecurangan itu akan merugikan masyarakat

Salah satu teori yang mendukung Whistleblowing adalah Prosocial Organizational Behavior Theory, yang mendefinisikan tentang perilaku / tindakan yang dilakukan oleh anggota sebuah organisasi terhadap individu, kelompok atau organisasi yang ditujukan untuk meningkatkan kesejahteraan individu, kelompok atau organisasi tersebut. Teori ini menerangkan bahwa perilaku positif yang dilakukan bukan hanya untuk kepentingan umum, tetapi juga untuk kepentingan diri inividu itu sendiri. Miceli dan 
Near dalam (Kreshastuti, 2014) menyatakan bahwa tipikal individu yang cenderung melakukan whistleblowing adalah yang menduduki jabatan professional, mempunyai reaksi positif terhadap pekerjaannya, lebih lama melayani, mempunyai kinerja yang baik, mempunyai kelompok kerja yang lebih besar dan mendapatkan tanggung jawab dari yang lain untuk menyatakan whistleblowing.

Peran whistleblower sangat diperlukan karena merupakan metode yang efektif sebagai deteksi dini terhadap kecurangan, selain itu penemuan secara awal dugaan penyimpangan memudahkan perusahaan untuk melakukan pembenahan dan memperkecil sorotan media yang dapat merugikan citra perusahaan. Pada prinsipnya, ada tiga alternatif mekanisme whistleblower. Mekanisme pertama bersifat anonymous, saat pelapor tidak perlu menunjukkan identitasnya sehingga kerahasiaan pelapor benar-benar terlindungi. Mekanisme kedua bersifat confidential, saat pelapor harus menyebutkan identitasnya, tetapi pihak berwenang mempunyai mekanisme untuk menjamin agar informasi dari pelapor tidak bocor. Yang ketiga bersifat open saat pelapor secara terbuka harus menyampaikan identitas dirinya. (Wijayanto, 2009)

Salah satu kondisi dimana auditor menghadapi konflik adalah ketika mereka menemukan informasi tertentu mengenai adanya kecurangan, kesalahan atau ketidakwajaran dalam sebuah laporan keuangan. Permasalahan yang timbul adalah apakah seorang auditor akan melaporkan temuan mereka (whistleblowing) ke otoritas yang lebih tinggi, melaporkan kepada pihak luar, membiarkannya, menutupinya, pura-pura tidak mengetahui atau bahkan konspirasi dengan oknum tersebut untuk mendapatkan keuntungan pribadi. Menjadi seorang whistleblower harus memiliki hati nurani dan keberanian. Kedua hal tersebut harus ada dalam diri seorang whistleblower, hati nurani ingin mengungkapkan apa yang tidak benar dan keberanian dalam mengungkapkan apa yang sebenarnya atau kesalahan yang terjadi dalam organisasi tersebut. Seperti yang kita ketahui, whistleblower di Indonesia ataupun di negara lain memiliki pengalaman pahit yang dilaluinya. Setelah mereka memilih menjadi whistleblower, mulai dari pemecatan, ancaman hingga mendapatkan tuduhan balik atas apa yang diungkapkannya. Dilihat dari nasib whistleblower tersebut sepertinya akan sulit menumbuhkan motivasi bagi pegawai atau karyawan yang mau menjadi whistleblower selanjutnya. Dilaporkan $90 \%$ dari whistleblower kehilangan pekerjaan mereka atau diturunkan dari jabatannya. (Semendawai, 2011). Menjadi seorang seorang whistleblower perlu mempertimbangkan beberapa risiko terlebih dahulu sebelum memutuskan apakah akan melaporkan informasi tersebut atau tidak. Namun konsistensi untuk melakukan whistleblowing demi kebaikan organisasi dapat dijadikan indikasi komitmen organisasi pegawai yang bersangkutan. Komitmen organisasional menjadi penting khususnya bagi organisasi yang ada saat ini dikarenakan dengan melihat sejauh mana keberpihakan seorang karyawan terhadap organisasi, dan sejauh mana karyawan tersebut berniat untuk memelihara keanggotaannya terhadap organisasi maka dapat diukur pula sebaik apa komitmen seorang karyawan terhadap organisasinya. Komitmen organisasi adalah sikap loyalitas karyawan terhadap organisasi, dengan cara tetap bertahan dalam organisasi, membantu mencapai tujuan organisasi dan tidak memiliki keinginan untuk meninggalkan organisasi dengan alasan apapun. (Yusuf, 2018).

Komitmen organisasi sebagai suatu kondisi psikologi yang dikarakteristikkan dengan meyakini serta menerima tujuan yang dimiliki oleh organisasi, berusaha dengan maksimal demi tercapainya organisasi yang unggul dan mempunyai keinginan yang kuat untuk tetap menjadi anggota organisasi. (Widyanto, dkk 2013). Sedangkan menurut (Robbins S. J., 2015) komitmen organisasi merupakan suatu keadaan dimana seorang karyawan memihak tujuantujuan organisasi dan berkeinginan untuk bisa mempertahankan keanggotaan dalam organisasi. Komitmen organisasi merupakan sikap kerja yang penting karena seseorang yang memiliki komitmen diharapkan bisa menunjukkan kesediaan untuk bekerja keras demi tercapainya tujuan organisasi serta memiliki keyakinan yang lebih besar untuk tetap bekerja disuatu perusahaan. (Kreitner, 2014)

Komitmen organisasional merupakan dimensi perilaku penting yang dapat digunakan untuk menilai kecenderungan karyawan untuk bertahan sebagai anggota organisasi. Menurut (Shaleh, 2018) hal tersebut dapat disimpulkan ke dalam tiga perilaku sebagai alasan mendasar, yakni: 1) adanya hubungan emosional karyawan terhadap organisasi sehingga membuat keinginan karyawan untuk tetap bertahan dalam organisasi; 2 ) adanya kepercayaan yang tinggi terhadap tujuan organisasi; 3) adanya rasa memiliki sehingga tercipta kemauan untuk berusaha dan membantu organisasi dalam mewujudkan tercapainya suatu tujuan yang diinginkan.

Steers dan Porter dalam (Yusuf, 2018) menggolongkan factor-faktor yang mempengaruhi terbentuknya komitmen organisasi, yaitu:

1. Karakteristik pribadi, yaitu kondisi potensi, kapasitas kemampuan, dan kemauan seorang karyawan sesuai kebutuhan dunia kerja. Karakteristik pribadi ini meliputi usia, jenis kelamin, tingkat pendidikan, masa kerja, motivasi dan nilai-nilai personal

2. Karakteristik pekerjaan, yaitu kondisi nyata berhubungan dengan pekerjaan itu sendiri, hal ini meliputi tantangan pekerjaan, kesempatan untuk 
berinteraksi social, identitas tugas, dan umpan balik

3. Karakteristik organisasi, yaitu desentralisasi dan otonomi tanggungjawab, partisipasi aktif karyawan, hubungan atasan dan bawahan, sifat dan karakteristik pimpinan serta caracara dalam pengambilan keputusan dan kebijakan

4. Sifat dan kualitas pengalaman kerja seorang karyawan dengan berbagai aspek di dalamnya dapat mempengaruhi komitmen karyawan

Menurut Luthan dalam (Shaleh, 2018) dimensi komitmen organisasi dapat dilihat dari tiga dimensi, yaitu: 1) Komitmen afektif yang merupakan bentuk emosi karyawan seperti identifikasi dan keterlibatan pada organisasi; 2) Komitmen kontinyu berupa keterlibatan mendasarkan pada keuntungan dan biaya, dan 3) Komitmen normative yang berupa keterikatan pada aturan atau keharusan. Seseorang yang berkomitmen tinggi terhadap organisasi akan lebih memikirkan tujuan dan keberlangsungan organisasinya daripada tujuan atau kepentingan individu dari rekan kerjanya. Oleh karena itu apabila seseorang berkomitmen tinggi terhadap organisasi, maka dia bisa saja menjadi whistleblower dengan tujuan yang baik terhadap organisasinya. Selain faktor internal tindakan whistleblowing juga dipengaruhi oleh faktor eksternal, yaitu iklim organisasi. Iklim organisasi memberikan arah dan memperkuat standar perilaku untuk mengendalikan anggota organisasi agar melaksanakan tugas dan tanggung jawabnya secara efektif dan efisien. Iklim organisasi sebagai bagian dari organisasi akan turut mewarnai cara bertindak anggota organisasi dalam aktivitas sehari-hari. Menurut (Wirawan, 2008), iklim organisasi adalah persepsi anggota organisasi (baik secara individual maupun kelompok serta mereka yang secara tetap berhubungan dengan organisasi, misalnya stakeholder, konsumen, konsultan dan kontraktor) mengenai berbagai hal yang ada atau terjadi di lingkungan internal organisasi secara rutin, dimana hal tersebut dapat mempengaruhi sikap dan perilaku organisasi serta kinerja anggota organisasi, yang kemudian menentukan kinerja organisasi.

Iklim organisasi dibagi menjadi dua yaitu: open climate (iklim terbuka) dan closed climate (iklim tertutup). Iklim terbuka ditandai kepercayaan dan semangat yang tinggi serta rendahnya perlawanan. Adanya kreativitas dan inovasi setiap anggota untuk menghasilkan yang terbaik. Iklim tertutup adalah kebalikan dari iklim terbuka yang ditandai dengan semangat rendah dan perlawanan tinggi. Pimpinan dan anggota memiliki gerakan sempit, menekankan pada hal-hal rutin, sibuk pada hal-hal sepele/ tidak penting dan tidak menunjukkan sedikitpun kepuasan. (Sagala, 2009). Litwin dan Stringers dalam (Muhammad, 2014) menyebutkan beberapa dimensi iklim organsasi, diantaranya: (1) rasa tanggung jawab, (2) standar atau harapan tentang kualitas pekerjaan, (3) ganjaran atau reward, (4) rasa persaudaraan dan (5) semangat tim. Sedangkan menurut Sagala (Sagala, 2009), dimensi iklim organisasi menunjukkan adanya rasa tanggung jawab, standar atau harapan tentang kualitas pekerjaan, rewars yang diperoleh sebagai pengakuan terhadap prestasi, saling mendukung dalam melaksanakan pekerjaan dan semangat yang kuat dalam tim kerja.

Iklim organisasi merupakan persepsi yang ada dalam anggota organisasi dan perasaan anggota organisasi mengenai elemen-elemen fundamental organisasi yang merefleksikan consensus sebagai kesepakatan antara anggota organisasi terkait elemen-elemen kunci organisasi yang terdiri atas system, praktik, dan gaya kepemimpinan. Menurut (Kusumaputri, 2018) aspek-aspek iklim organisasi, yaitu: (1) Struktur, hal ini mengacu pada bagaimana anggota merasakan Batasan-batasan organisasi dan aturan-aturannya, (2) Tanggung Jawab, aspek ini concern dengan bagaimana anggota merasa mampu membuat keputusan tanpa harus meminta konfirmasi dengan atasan langsung. Kondisi ini melibatkan pengetahuan mengenai peran seseorang dan memastikan setiap pekerjaan dapat dikerjakan. (3) Imbalan, aspek ini berfokus pada bagaimana anggota memaami penghargaan untuk apa yang telah mereka kerjakan. (4) Risiko, aspek ini menggambarkan risiko atau tantangan yang dikaitkan dengan pekerjaan tertentu. (5) Kehangatan, Fokus pada aspek ini adalah perasaan keakraban antara satu anggota dengan anggota lainnya dalam kelompok maupun organisasi secara keseluruhan. (6) Dukungan, tujuannya adalah untuk mengukur bagaimana pemahaman pada kesediaan pengelola dan kolega untuk saling memberikan dukungan dan bantuan pada kesulitan yang dihadapi. (7) Konflik, hal ini merepresentasikan keberadaan pengelola dan anggota untuk terbuka mendiskusikan permasalahan-permasalahan daripada mengabaikan permasalahan . (8) Identitas, aspek identitas mengukur sejauh mana anggota merasa bernilai dalam kelompok sebagai bagian organisasi

Meskipun penelitian mengenai whistleblowing sudah banyak dilakukan, namun penelitian sebelumnya meneliti tindakan whistleblowing dikalangan akuntan perusahaan, auditor swasta maupun pemerintah, atau pegawai pajak. Sedangkan di kalangan auditor dengan spesifikasi auditor internal pemerintah masih jarang dilakukan. Auditor internal berada dalam situasi yang unik dimana auditor internal merupakan bagian dari organisasi. Subjek yang akan dihadapi oleh auditor internal tidak lain adalah rekan kerja sendiri atau bahkan pihak yang memiliki level jabatan yang lebih tinggi sehingga seringkali seorang auditor internal dipertanyakan independensi dan objektivitas agar menghasilkan audit yang berkualitas, sedangkan peran sebagai pembimbing dan konsultan menuntut 
sikap mau bekerja sama dan sifat mau membantu auditee. (Diani, 2017).

Dengan pertimbangan tersebut, penelitian ini mencoba untuk mengidentifikasi faktor yang mempengaruhi tindakan whistleblowing dengan mengintegrasikan variabel individu yakni komitmen organisasi dan variabel organisasi yaitu iklim organisasi. Hasil penelitian ini diharapkan bermanfaat sebagai masukan dalam merumuskan berbagai kebijakan terkait dengan posisi, tugas, dan fungsi auditor dalam struktur tata kelola untuk menciptakan tata kelola pemerintahan yang baik dan besih. Berdasarkan pemikiran tersebut maka hipotesis yang diajukan dalam penelitian ini adalah sebagai berikut:

1. Ada pengaruh komitmen organisasi terhadap tindakan whistleblowing

2. Ada pengaruh iklim organisasi terhadap tindakan whistleblowing

3. Ada pengaruh komitmen organisasi dan iklim organisasi terhadap tindakan whistleblowing

\section{METODOLOGI PENELITIAN}

Penelitian ini bertujuan untuk mengetahui ada tidaknya pengaruh antara variabel variabel penelitian dan menguji hipotesis yang telah dirumuskan untuk memprediksi besarnya variabel, bentuk hubungan dan menentukan arah dan besarnya. Penelitian ini menggunakan pendekatan kuantitatif kausal, jenis penelitian kausal dirasa sesuai degan inti dari penelitian ini yang ingin mencari pengaruh dari komitmen organisasi $\left(\mathrm{X}_{1}\right)$ dan Iklim Organisasi $\left(\mathrm{X}_{2}\right)$ terhadap Tindakan Whistleblowing (Y). Melalui pengolahan data secara statistic diharapkan dapat diketahui sejauh mana pengaruh antara ketiga variabel yang diteliti.

Teknik sampling yang digunakan adalah purposive sampling. Responden dalam penelitian ini adalah pegawai Badan Pengawasan Keuangan dan Pembangunan (BPKP). Adapun karakteristik responden dalam penelitian ini adalah: (1) Pegawai Negeri Sipil (PNS) yang menjabat sebagai auditor internal di BPKP RI, (2) Masa kerja minimal satu tahun, (3) Masih aktif dalam melakukan pemeriksaan pada periode penelitian. Penelitian dilakukan di kantor Badan Pengawasan Keuangan dan Pembangunan (BPKP), Jakarta. Penelitian dilakukan pada 1 November 2018 sampai 1 Desember 2018. Komitmen organisasi diukur menggunakan indikator yang diadopsi dari Luthan dalam (Shaleh, 2018), yaitu: (1) Komitmen afektif, (2) Komitmen kontinyu, (3) Komitmen normative. Iklim organisasi diukur menggunakan indikator yang diadopsi dari Litwin dan Stringers dalam (Muhammad, 2014) menyebutkan dimensi iklim organisasi, yaitu: (1) rasa tanggung jawab, (2) standar atau harapan tentang kualitas pekerjaan, (3) ganjaran atau reward, (4) rasa persaudaraan dan (5) semangat tim. Sedangkan tindakan whistleblowing diukur dengan menggunakan Multidimensional Ethics Measure (MEM) yang terdiri dari tiga dimensi, yaitu: (1) Moral Equity, (2) Relativisme , (3) Contractualism.

Semua skala yang digunakan dalam penelitian ini menggunakan model skala Likert yang tertinggi adalah 4 dan terendah adalah 1 . Jawaban responden untuk pertanyaan positif diberi skor 4 (empat) untuk Sangat Setuju (SS), skor 3 (tiga) untuk Setuju (S), skor 2 untuk Pilihan Tidak Setuju (TS), skor 1 (satu) untuk pilihan Sangat Tidak Setuju. Jawaban responden untuk pernyataan negative diberi skor sebaliknya. Peneliti tidak memberikan alternatif pilihan ragu-ragu atau netral karena seringkali responden memiliki kecenderungan menjawab ke tengah, dan tidak dapat menunjukkan kecenderungan jawaban subjek ke arah setuju atau tidak setuju sehingga banyak data dan informasi penelitian yang tidak dapat diungkap oleh peneliti.

\section{HASIL DAN PEMBAHASAN}

\section{Uji Validitas}

Uji validitas dilakukan dengan tujuan untuk mengetahui validitas dari item-item pada kuesioner. dalam penarikan kesimpulan dari data. Pengujian validitas dalam penelitian ini dilakukan kepada 200 responden dengan menghitung koefisien korelasi, selanjutnya nilai korelasi atau $r$ hitung dibandingkan dengan $\mathrm{r}$ tabel. Suatu item pernyataan dinyatakan valid jika nilai $r$ hitung $>r$ tabel. Berikut pemaparannya.

Tabel 1. Hasil Uji Validitas Variabel Komitmen Organisasi

\begin{tabular}{ccc}
\hline No Item & $\begin{array}{c}\text { Corected Item } \\
\text { Total } \\
\text { Correlation }\end{array}$ & Keterangan \\
\hline Item 1 & .428 & Valid \\
Item 2 & .596 & Valid \\
Item 3 & .474 & Valid \\
Item 4 & .700 & Valid \\
Item 5 & .553 & Valid \\
Item 6 & .450 & Valid \\
Item 7 & .589 & Valid \\
Item 8 & .506 & Valid \\
Item 9 & .372 & Valid \\
\hline
\end{tabular}

Sumber: Data yang diolah (2018)

Tabel 2. Hasil Uji Validitas Variabel Iklim Organisasi

\begin{tabular}{ccc}
\hline \multicolumn{3}{c}{ Organisasi } \\
No Item & $\begin{array}{c}\text { Corected Item } \\
\text { Total } \\
\text { Correlation }\end{array}$ & Keterangan \\
\hline Item 1 & .603 & Valid \\
Item 2 & .529 & Valid \\
Item 3 & .526 & Valid \\
Item 4 & .433 & Valid \\
Item 5 & .464 & Valid \\
Item 6 & .577 & Valid \\
Item 7 & .530 & Valid \\
Item 8 & .360 & Valid \\
Item 9 & .643 & Valid \\
\hline
\end{tabular}

Sumber: Data yang diolah (2018) 
Tabel 3

Hasil Uji Validitas Variabel Tindakan Whistleblowing

\begin{tabular}{ccc}
\hline No Item & $\begin{array}{c}\text { Corected Item } \\
\text { Total } \\
\text { Correlation }\end{array}$ & Keterangan \\
\hline Item 1 & .444 & Valid \\
Item 2 & .436 & Valid \\
Item 3 & .453 & Valid \\
Item 4 & .395 & Valid \\
Item 5 & .455 & Valid \\
Item 6 & .531 & Valid \\
Item 7 & .473 & Valid \\
Item 8 & .458 & Valid \\
Item 9 & .332 & Valid \\
Item 10 & .537 & Valid \\
Item 11 & .598 & Valid \\
Item 12 & .371 & Valid \\
Item 13 & .355 & Valid \\
Item 14 & .490 & Valid \\
Item 15 & .564 & Valid \\
\hline
\end{tabular}

Sumber: Data yang diolah (2018)

\section{Uji Reliabilitas}

Uji reliabilitas digunakan untuk menguji tingkat keterandalan instrumen penelitian. Angket yang reliabel, jika datanya benar-benar sesuai dengan kenyataan, berapa kalipun diambil, akan tetap memberikan hasil yang sama atau konsisten. (Setiawan, 2015)

\section{Tabel 4}

Uji Reliabilitas

\begin{tabular}{ccc}
\hline Variabel & Cronbach's Alpha & Keterangan \\
\hline $\begin{array}{c}\text { Komitmen } \\
\text { Organsiasi }\end{array}$ & .815 & Reliabel \\
Iklim Organisasi & .833 & Reliabel \\
$\begin{array}{c}\text { Tindakan } \\
\text { Whistleblowing }\end{array}$ & .871 & Reliabel \\
\hline Sumber: Data yang diolah (2018) &
\end{tabular}

Reliabilitas dalam penelitian ini menggunakan metode Alpha Cronbach. Kriteria suatu skala dikatakan reliabel apabila koefisien reliabilitas menunjukkan angka lebih dari 0.6 (Siregar, 2013)

Perhitungan reliabilitas terhadap alat ukur komitmen organisasi, iklim organisasi dan tindakan whistleblowing menghasilkan koefisien reliabilitas lebih dari 0.6 sehingga dapat disimpulkan bahwa ketiga variabel tersebut reliabel sebagai alat ukur.

\section{Uji Asumsi Klasik}

\section{a. Uji Normalitas}

Pengujian normalitas bertujuan untuk menguji apakah dalam model regresi, variabel bebas dan variabel terikat, keduanya memiliki distribusi normal atau tidak. Model regresi yang baik adalah data yang berdistribusi normal atau mendekati normal. (Sujarweni, 2014)

Uji normalitas yang digunakan peneliti menggunakan Kolmogorov Smirnov test. Ketentuannya adalah apabila nilai signifikansi $>(0.05$ atau $5 \%)$ maka artinya residual berdistribusi normal.

Tabel 5

Uji Kolmogorov Smirnov

\begin{tabular}{ll}
\hline & Unstandardized Residual \\
\hline $\mathrm{N}$ & 200 \\
\hline Most Extreme Absolute & .096 \\
Kolmogorov Smirnov Z & 1.181 \\
Asymp. Sig (2-tailed) & .123
\end{tabular}

Sumber: Data yang diolah (2018)

Berdasarkan tabel 5, nilai signifikansi bernilai 0.1213 sehingga dapat dipastikan nilainya lebih besar dari 0.05 . Dengan demikian maka artinya residual berdistribusi normal sehingga model regresi yang dihasilkan dapat digunakan untuk pengambilan keputusan.

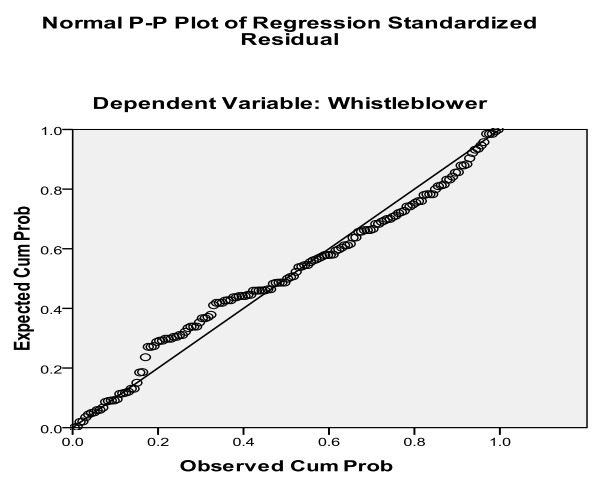

Sumber: Data yang diolah (2018)

Gambar 1. Uji Normalitas

Hasil uji normalitas yang diperoleh dari penggunaan grafik normal probability plot dalam penelitian ini menunjukkan bahwa titik-titik menyebar disekitar garis diagonal dan penyebarannya pun mengikuti garis diagonal. Sehingga dapat ditarik kesimpulan bahwa penyebaran data dalam penelitian ini sudah terdistribusi dengan normal atau sudah memenuhi asumsi normalitas 


\section{b. Uji Multikolinearitas}

Multikolinearitas dapat terjadi jika adanya hubungan linier yang sempurna atau hampir sempurna diantara beberapa atau seluruh variabel independen dalam model regresi. Uji multikolinearitas memiliki tujuan untuk menguji keberadaan korelasi antar variabel bebas dalam model regresi. Model regresi yang baik seharusnya tidak terjadi korelasi diantara variabel bebas. Untuk menguji keberadaan multikolinearitas dapat dilakukan dengan cara menganalisis korelasi antar variabel dengan menggunakan perhitungan tollerance dan Variance Inflation Factor (VIF). (Sujarweni, 2014)

\section{Tabel 6. Uji Multikolinearitas}

\begin{tabular}{ccc}
\hline Model & $\begin{array}{c}\text { Collinearity } \\
\text { Statistics }\end{array}$ & \\
\hline & Tolerance & VIF \\
\hline Constant & & \\
Komitmen & & 1.185 \\
Organisasi & .844 & 1.185 \\
Iklim & .844 & \\
Organisasi & &
\end{tabular}

Sumber: Data yang diolah (2018)

Hasil uji ini memperlihatkan bahwa nilai tollerance variabel independen, yaitu komitmen organisasi dan iklim organisasi $>0.10$. Sementara nilai VIF yang didapat $<10$. Dengan demikian diantara variabel independen tidak terjadi multikolinearitas sehingga mempertegas kelayakan model regresi yang dijalankan.

\section{c. Uji Heteroskedastisitas}

Uji heteroskedastisitas bertujuan untuk menguji apakah dalam model regresi terjadi ketidaksamaan variance residual satu pengamatan ke pengamatan yang lain. (Ghozali, 2011)

\section{Tabel 7. Uji Heteroskedastisitas}

\begin{tabular}{cccccc}
\hline Model & $\begin{array}{c}\text { Unstanda } \\
\text { rdized } \\
\text { Coefficie } \\
\text { nts }\end{array}$ & \multicolumn{5}{c}{$\begin{array}{c}\text { Standa } \\
\text { rdized } \\
\text { Coeffic } \\
\text { ients }\end{array}$} & & \\
\hline & $\mathrm{B}$ & $\begin{array}{c}\text { Std } \\
\text { Error }\end{array}$ & Beta & $\mathrm{t}$ & Sig \\
\hline $\begin{array}{c}\text { Consta } \\
\text { nt }\end{array}$ & -9.902 & 3.323 & & - & .003 \\
$\begin{array}{c}\text { Komit } \\
\text { men }\end{array}$ & .084 & .048 & .192 & 1.738 & .084 \\
$\begin{array}{c}\text { Organi } \\
\text { sasi }\end{array}$ & & & & & \\
$\begin{array}{c}\text { Iklim } \\
\text { Organi } \\
\text { sasi }\end{array}$ & .074 & .049 & .166 & 1.504 & .135 \\
\hline
\end{tabular}

Sumber: Data yang diolah (2018)

Pengujian heteroskedastisitas dengan menggunakan Uji Glejser, seperti yang tampak pada tabel 7 menunjukkan bahwa model uji terbebas dari heteroskedastisitas. Hal ini terbukti dengan nilai signifikansi yang lebih besar dari $\alpha$ 5\%.

\section{Uji Hipotesis}

\section{a. Koefisien Determinasi $\left(\mathbf{R}^{2}\right)$}

Uji koefisien determinasi bertujuan untuk mengetahui seberapa besar (presentase) variabel independen berpengaruh terhadap variabel dependen. Nilai koefisien determinasi adalah antara nol dan 1. Apabila nilai koefisien determinasi (adjusted $\mathrm{R}$ Square) lebih besar dari 0.05 atau mendekati 1 maka dapat disimpulkan bahwa variabel independen memberikan hampir semua informasi yang dibutuhkan untuk memprediksi variabel dependen.

Tabel 6. Uji R

\begin{tabular}{|c|c|c|c|c|}
\hline Model & $\mathrm{R}$ & $\begin{array}{c}\mathrm{R} \\
\text { Square }\end{array}$ & $\begin{array}{l}\text { Adjusted } \\
\text { R Square }\end{array}$ & $\begin{array}{c}\text { Std. } \\
\text { Error of } \\
\text { the } \\
\text { Estimate }\end{array}$ \\
\hline & .839 & .704 & .700 & 5.826 \\
\hline
\end{tabular}

Angka $\mathrm{R}$ Square $\left(\mathrm{R}^{2}\right)$ menunjukkan koefisien determinasi. Nilai koefisien determinasi $\left(\mathrm{R}^{2}\right)$ dalam penelitian ini diperoleh dengan menghitung kuadrat dari nilai koefisien korelasi dikali $100 \%$ sehingga nilai koefisien determinasi yang didapat adalah $70,4 \%$, artinya sumbangan pengaruh komitmen organisasi dan iklim organisasi sebesar 70,4\% sedangkan sisanya sebesar $29,6 \%$ dipengaruhi oleh variabel lain yang tidak dimasukkan dalam penelitian ini.

\section{b. Uji Hipotesis Simultan (Uji F)}

Pengujian hipotesis secara simultan (Uji F) digunakan untuk mengetahui besarnya pengaruh yang bermakna variabel independen secara bersamasama (simultan) terhadap variabel dependen.

Tabel 7. Uji F

\begin{tabular}{ccccc}
\hline Model & $\begin{array}{c}\text { Sum of } \\
\text { Squares }\end{array}$ & $\begin{array}{c}\text { Mean } \\
\text { Square }\end{array}$ & F & Sig \\
\hline Regression & 11889.654 & 5944.827 & 175.159 & .000 \\
Residual & 4989.120 & 33.940 & & \\
Total & 16878.773 & & & \\
\hline Sumber: Data yang diolah (2018) & &
\end{tabular}

Berdasarkan tabel diatas, diperoleh $\mathrm{F}$ hitung sebesar 175.159 dengan nilai signifikansi $0.000<0.05$ sehingga dapat ditarik kesimpulan bahwa komitmen organisasional dan iklim organisasi secara bersamasama mempengaruhi tindakan whistleblowing. Hal ini mengindikasikan bahwa komitmen organisasi dan iklim organisasi layak digunakan untuk memprediksi tindakan whistleblowing sehingga pengujian hipotesis penelitian dapat dilakukan. Dengan demikian dapat ditarik kesimpulan terdapat hubungan yang positif dan signifikan komitmen organisasi dan iklim organisasi terhadap tindakan whistleblowing. 
Semakin tinggi komitmen organisasi dan iklim organisasi maka tindakan whistleblowing juga semakin tinggi. Sebaliknya semakin rendah komtimen organisasi dan iklim organisasi maka semakin rendah tindakan whistleblowing. Dengan demikian tindakan whistleblowing dapat di tingkatkan melalui kesadaran, integritas serta penerapan komitmen organisasi yang tinggi dalam diri pegawai serta dan iklim organisasi yang kondusif

Tabel 7. Uji t

\begin{tabular}{cccccc}
\hline Model & $\begin{array}{c}\text { Unstand } \\
\text { ardized } \\
\text { Coefficie } \\
\text { nts }\end{array}$ & & $\begin{array}{c}\text { Standa } \\
\text { rdized } \\
\text { Coeffi } \\
\text { cients }\end{array}$ & & \\
\hline & $\mathrm{B}$ & $\begin{array}{c}\text { Std } \\
\text { Error }\end{array}$ & Beta & t & Sig \\
\hline $\begin{array}{c}\text { Consta } \\
\text { nt }\end{array}$ & 29.713 & 5.268 & & 5.641 & .000 \\
\hline $\begin{array}{c}\text { Komit } \\
\text { men }\end{array}$ & .527 & .057 & .513 & 9.242 & .000 \\
$\begin{array}{c}\text { Organi } \\
\text { sasi }\end{array}$ & & & & & \\
\hline $\begin{array}{c}\text { Iklim } \\
\text { Organi } \\
\text { sasi }\end{array}$ & .273 & .049 & .312 & 5.615 & .000 \\
\hline $\begin{array}{c}\text { Sumber: Data yang diolah }(2018) \\
\end{array}$ & & & & \\
\hline
\end{tabular}

\section{c. Uji Hipotesis Parsial (Uji t)}

Tujuan dari Uji t adalah untuk mengetahui apakah secara parsial variabel independen berpengaruh signifikan terhadap variabel dependen. Uji ini dilakukan untuk memeriksa lebih lanjut variabel independen manakah yang berpengaruh signifikan terhadap tindakan whistleblowing.

1) Hipotesis 1 : Pengaruh Komitmen Organisasi terhadap Tindakan Whistleblowing

Hasil uji hipotesis 1 diperoleh nilai t hitung variabel komitmen organisasi sebesar 9.242 dengan nilai signifikansi $0.000<0.05$, maka dapat ditarik kesimpulan bahwa komitmen organisasi berpengaruh positif dan signifikan terhadap tindakan whistleblowing. Dengan demikian $\mathrm{H}_{0}$ ditolak, dan hipotesis alternatif $\mathrm{H}_{1}$ “ komitmen organisasi memiliki pengaruh positif dan signifikan terhadap tindakan whistleblowing" Diterima. Semakin tinggi komitmen organisasi pegawai maka semakin tinggi pula tindakan whistleblowing

2) Hipotesis 2 : Pengaruh Iklim Organisasi terhadap whistleblowing

Hasil uji hipotesis 2 diperoleh nilai t hitung variabel iklim organisasi sebesar 5.615 dengan nilai signifikansi $0.000<0.05$, maka dapat ditarik kesimpulan bahwa iklim organisasi berpengaruh positif dan signifikan terhadap tindakan whistleblowing. Dengan demikian $\mathrm{H}_{0}$ ditolak, dan hipotesis alternatif $\mathrm{H}_{2}$ " iklim organisasi memiliki pengaruh positif dan signifikan terhadap tindakan whistleblowing " Diterima. Semakin baik iklim organisasi maka semakin tinggi tindakan whistleblowing

\section{Analisis Regresi Linier Berganda}

Tujuan dari analisis regresi berganda adalah untuk menguji dua atau lebih variabel independen terhadap variabel dependen. Persamaan linier antara komitmen organisasi dan iklim organisasi terhadap kinerja karyawan adalah sebagai berikut:

$$
\mathrm{Y}^{\wedge}=29.713+.527 \mathrm{X}_{1}+.273 \mathrm{X}_{2}
$$

Dari persamaan regresi diatas diperoleh nilai konstanta sebesar 29.713 menunjukkan bahwa jika variabel bebas yang terdiri dari komitmen organisasi dan iklim organisasi bernilai tetap atau tidak ada perubahan $=0$, maka tindakan whistleblowing yang dilakukan pegawai tergolong tinggi karena $\alpha$ melebihi 1, untuk itu semua variabel bebas yang mempengaruhi tindakan whistleblowing dalam penelitian ini sebaiknya dipertahankan atau bahkan ditingkatkan.

Koefisien regresi komitmen organisasi $\left(b_{1}\right)$ bernilai 0.527 menunjukkan hubungan positif (searah) antara komitmen organisasi dengan tindakan whistleblowing. Hasil ini menunjukkan semakin baik implementasi komitmen organisasi yang dilakukan oleh pegawai akan diikuti dengan semakin tinggi tindakan whistleblowing. Implementasinya antara lain organisasi diharapkan dapat mendorong, menumbuhkan atau meningkatkan komitmen organisasi auditor melalui pendidikan, pelatihan, seminar, workshop, dukungan organisasi, pemberian reward, jaminan kerahasiaan dan perlindungan hukum terhadap pelapor sehingga dapat meningkatkan sikap profesionalisme dalam pengungkapan fraud.

Koefisien regresi iklim organisasi $\left(b_{2}\right)$ yang bernilai 0.273 , menunjukkan hubungan positif searah) antara iklim organisasi dengan tindakan whistleblowing. Hasil ini menunjukkan semakin baik iklim organisasi perusahaan akan diikuti dengan semakin baik tindakan whistleblowing. Diharapkan kepada Badan Pengawasan Keuangan dan Pembangunan Republik Indonesia dapat mempertahankan atau meningkatkan iklim organisasi yang supportif diantaranya dengan memberikan lingkungan kerja yang kondusif, nyaman sehingga mampu mendorong setiap pegawai untuk bekerja dan berprestasi dengan baik. Perlunya sosialisasi tindakan whistleblowing yang menyangkut tata cara atau prosedur pelaporan, perlindungan hukum bagi pelapor. Hal ini telah dilakukan antara lain melalui system whistleblowing yang memungkinkan peran aktif dari pegawai untuk melaporkan adanya pelanggaran dan dugaan atau indikasi pelanggaran yang dapat diakses pada website BPKP. Serangkaian sosialisasi dan kerja sama juga telah dilakukan diantaranya dengan kementrian maupun lembaga pemerintah seperti Kementrian Keuangan, Badan Pemeriksa Keuangan (BPK), Pusat Pelaporan dan Analisis Transaksi Keuangan (PPATK), Komisi Pemberantasan Korupsi (KPK), Lembaga Perlindungan Saksi dan Korban (LPSK). 
Pimpinan, atasan membuka ruang interaksi dan komunikasi yang terbuka dan sehat melalui kegiatan rapat formal maupun informal yang dilakukan setiap minggunya, hal ini perlu ditingkatkan lagi agar pegawai tidak merasa takut atau sungkan dalam memberikan saran, ide, alternatif solusi pemecahan masalah, atau bahkan dapat meningkatkan motivasi pegawai untuk mencegah atau melaporkan fraud.

\section{KESIMPULAN}

Berdasarkan hasil penelitian dapat disimpulkan bahwa komitmen organisasi dan iklim organisasi yang ada di Badan Pengawasan Keuangan dan Pembangunan (BPKP) tergolong baik, hal ini didukung oleh hasil penelitian yang menunjukkan bahwa secara parsial maupun simultan komitmen organisasi dan iklim organisasi berpengaruh positif dan signifikan terhadap tindakan whistleblowing. Untuk penelitian selanjutnya hendaknya mencoba mengeksplorasi variabel lain yang mempengaruhi seseorang untuk melakukan whistleblowing sehingga dapat menyempurnakan model penelitian ini dan memprediksi secara lebih akurat. Variabel-variabel lain yang mungkin menarik untuk diuji antara lain: demografi, motivasi, persepsi dukungan organisasi, trait, konformitas, etos kerja, etika profesi. Selain itu peneliti berikutnya diharapkan dapat mendesain penelitian mengenai whistleblowing yang fokus pada jenis whistleblowing yang spesifik. Misalnya fokus pada internal whistleblowing atau eksternal whistleblowing.

\section{REFERENSI}

Arsana, I. P. (2018). Etika Profesi Insinyur: Membangun Sikap Profesionalisme Sarjana Teknik. Yogyakarta: Deepublish.

Diani, R. C. (2017). 2017. Jurnal Tata Kelola dan Akuntabilitas Keuangan Negara Volume 3 No.2, 131-149.

Ghozali, I. (2011). Aplikasi Analisis Multivariate dengan Program IBM SPSS 19. Semarang: Badan Penerbit Universitas Diponegoro.

Hartanto, F. M. (2009). Paradigma Baru Manajemen Indonesia: Menciptakan Nilai dengan Bertumpu pada Kebijakan dan Potensi Insani . Bandung : Mizan.

Kreitner, R. d. (2014). Organizational BehavioralEd. 5. Boston: McGraw-Hill.

Kreshastuti, D. (2014). Analisis Faktor-Faktor yang Mempengaruhi Intensi Auditor untuk Melakukan Tindakan Whistleblowing. Diponegoro Journal of Accounting, 1-15.
Kusumaputri, E. S. (2018). Komitmen Pada Perubahan (Perubahan Organisasi Dalam Perspektif Islam dan Psikologi. . Yogyakarta:: Deepublish.

Muhammad, A. (2014). Komunikasi Organisasi. Jakarta : Bumi Aksara.

Priyatno, D. (2009). 5 Jam Belajar Olah Data dengan SPSS 17. Jakarta: Andi.

Robbins, S. \&. (2008). Perilaku Organisasi. Jakarta: Salemba 4.

Robbins, S. J. (2015). Perilaku Organisasi (Organziational Behavior). Jakarta: Salemba Empat.

Sagala, S. (2009). Memahami Organisasi Pendidikan . Bandung : Alfabeta.

Semendawai, A. H. (2011). Memahami Whistleblowing . Jakarta : Lembaga Perlindungan Saksi dan Korban (LPSK).

Setiawan, B. 2. (2015). Teknik Praktis Analisis Data Penelitian Sosial dan Bisnis dengan SPSS. . Yogyakarta: Andi.

Shaleh, M. (2018). Komitmen Organisasi terhadap Kinerja Pegawai. Makasar: Aksara Timur.

Siregar, S. (2013). Metode Penelitian Kuantitatif: Dilengkapi Perbandingan Perhitungan Manual dan SPSS. . Jakarta: Kencana Prenada Media Group.

Soetopo, H. (2012). Perilaku Organisasi: Teori dan Praktik di Bidang Pendidikan . Bandung: Remaja Rosdakarya.

Sujarweni, V. (2014). SPSS untuk Penelitian . Yogyakarta: Pustaka Baru Pers.

Tuanakotta, M. T. (2010). Akuntansi Forensik dan Audit Investigatif. Jakarta: Salemba Empat .

Usman, H. (2010). Manajemen: Teori, Praktik, dan Riset Pendidikan . Jakarta: Bumi Aksara.

Wijayanto. (2009). Korupsi Mengkorupsi Indonesia: sebab, akibat dan prospek pemberantasan. Jakarta: Gramedia Pustaka Utama.

Wirawan. (2008). Budaya dan Iklim Organisasi . Jakarta: Salemba 4.

Yusuf, M. R. (2018). Komitmen Organisasi: Definisi, Dipengaruhi dan Mempengaruhi. Makasar: Nas Media Pustaka.

\section{PROFIL PENULIS}

Devy Sofyanty, S.Psi, MM. Lahir di Jakarta tanggal 17 Desember 1984. Menyelesaikan pendidikan S-1 di Fakultas Psikologi Universitas Persada Indonesia Y.A.I dan melanjutkan pada program Magister Manajemen Universitas BSI Bandung 